\title{
INNOVATIVE PRINCIPLES OF THE ORGANIZATION, USE AND PROTECTION OF AGRICULTURAL LAND
}

\author{
E. Butenko, candidate of economic sciences, associate professor \\ V. Stepanets, magistrate \\ National University of Life and Environmental Sciences of Ukraine \\ Email:vova-stepanets@ukr.net
}

\begin{abstract}
The article considers innovative principles of development are explored. The role of land monitoring in the management of agricultural land use and the preconditions for improving agriculture has been highlighted. The concept of sustainable development of the use of land resources is proposed. The foreign experience and trends of sustainable land use development are described.
\end{abstract}

Key words. Land monitoring, innovative principles, land use, land protection.

\section{Relevance of the problem.}

The state of development of agricultural land use has exhausted the possibilities of ill-considered use of land resources, which is inherent in the early stages of industrialization and is carried out by traditional technologies. It becomes increasingly clear that special attention should be paid to improving the conditions and the search for concepts for effective land use.

The negative dynamics of soil fertility necessitates the search for more advanced agricultural systems. Modern intensification of agricultural production due to violation of the boundaries of its main directions has become extensive. The key problems that arose in the practice of agricultural production were: reducing the fertility of the land, environmental degradation, reducing the quality of products, significant losses of external and internal markets for agricultural products [7].
The aim is to study the foundations of innovative development and protection of agricultural land.

An analysis of recent research and publications on innovative development of effective land use was researched in scientific works of domestic scientists: E.V. Butenka, Iristysheva, A.Ya. Sokhnicha, R.A. Kharitonenko, A.M. Tretyak. At the same time, the modern methodological base does not fully disclose the methodological approaches to the formation of the mechanism of innovative management of agricultural land use.

Butenko Ye.V. and Kharitonenko R.A. noted that now accurate information about the state of the earth's surface is obtained by aerial photo geodetic surveys, based on the use of aerospace images of the earth's surface. The experience of countries that are actively using remote sensing means of land shows the possibility of monitoring the actual state of land resources. It enables to detect changes in a timely manner, to evaluate 
them and to eliminate or eliminate the consequences of negative processes. [5]

Sokhnich A.Ya. and Iristysheva I.O. believe that effective and sustainable development of the region and the state as a whole can only be achieved if the newest innovative technologies are used, since they are capable of bringing the country's economy to a new world level.[12]

Tretyak A.M. noted that an efficient and dynamic land management system is one of the main conditions for solving current social, ecological and economic problems of Ukraine. [13]

\section{Presenting main material.}

The basis for decision-making with efficient land use is the information that the landowner or land user receives. On the basis of such information it is possible to assess the effectiveness of measures that are consistent with market realities. There are, of course, many ways of obtaining such information, but the monitoring of land is of particular interest, which allows you to obtain operational and systematic information about the research object.

Monitoring as a new trend in the control of soil cover began to develop from the late 70-80s of the last century. Then the problem became global in countries with developed agrarian production, which faced soil degradation after excessive chemical and mechanical loading on them, which had a temporary success. That is why in these countries, from the end of the last century, newest ground protection systems of agriculture began to develop [11].

In modern conditions, monitoring of degradation processes in the context of Ukraine's land resources is virtually absent. [6]
The object of the research is the territory of the VP NUBiP Ukrainy «Velykosnitynske navchalno-doslidne hospodarstvo im. O.V. Muzychenka», which is characterized by manifestations of degradation processes. The problem of water erosion of soils is urgent for the territory of the economy. Under the influence of temporary watercourses, ravines grow, produce a longitudinal and transverse profile, become the cause of increased erosion of adjacent areas. Strengthening degradation processes under the new organizational and legal forms of land use in Ukraine suggests that traditional methods of monitoring and monitoring the state of the agrosphere do not meet modern information requirements. [3] (Fig.1.)

Also, the use in agriculture of lands that are eroded is economically and environmentally disadvantageous, since in such areas we lose the most valuable resource in the form of a fertile soil layer, seed and fuel materials used in the cultivation of degraded lands, with the fact that in such lands you can not get the expected yield in the form of agricultural products.

Therefore, one of the examples of effective use of territories exposed to water erosion in the form of formation of ravines is the United States foreign experience. To minimize the consequences of water erosion, a system of soil and protective measures throughout the country was introduced. The best results for soil conservation and minimization of the effects of water erosion across the state were achieved in Missouri. As a result of the removal of erosion-hazardous areas from cultivation, they managed to optimize the area of arable land, reduce the loss of fertile soil and increase the area of forest lands that best stabilize the ecological environment of the egion (Fig. 2). 


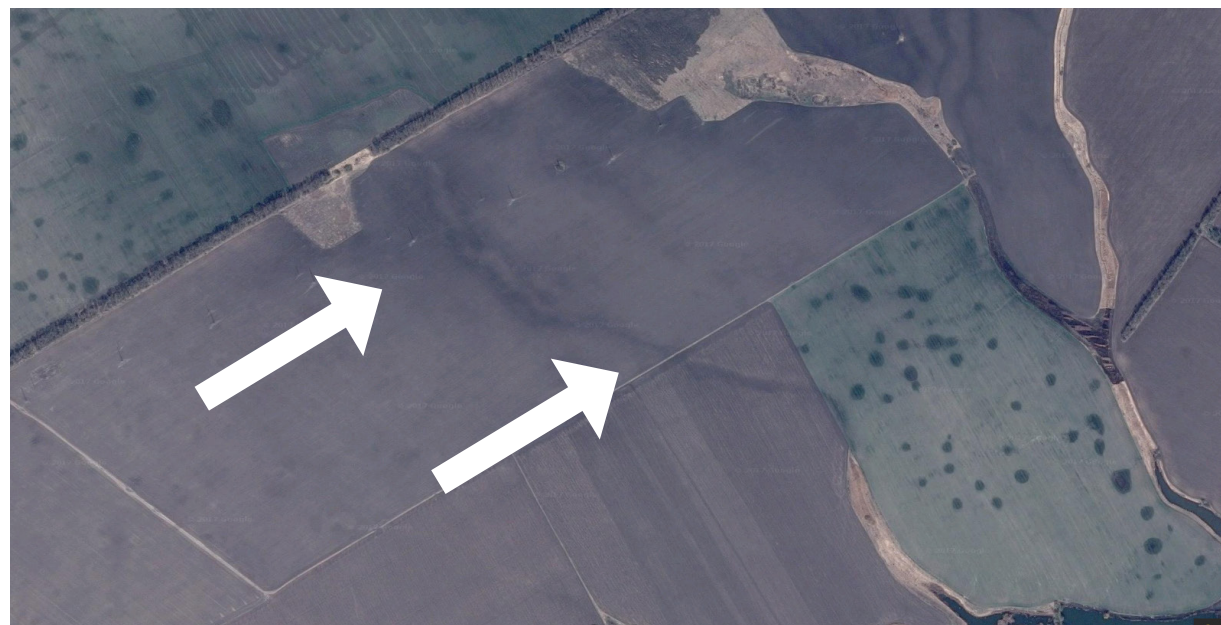

Figure 1 An example of the manifestation of erosion processes in the form of a continuation of the ravine on the territory of the VP NUBiP Ukrainy «Velykosnitynske navchalno-doslidne hospodarstvo im. O.V. Muzychenka»

The land with erosion-hazardous slope of the area is removed from agricultural production by pre-fixing it with perennial grasses, this approach has made it possible to minimize the formation of ravines, the flushing of the fertile soil layer and ungrounded cultivation of degraded land in the territory of these farms. To some extent, it's a pity that developed countries have long used integrated approaches to address specific problems, while we have not yet learned how to solve the problem of losing our national treasure - fertile soil in a comprehensive way, using information on the state of the earth.

The total area of degraded lands is 16.02 ha. Transformation of these areas under perennial plantations will have a significant ecological and soil protection effect. Table 1 shows the area of degraded land for each individual object.

The given area is proposed to be planted wi th herbaceous vegetation. For this purpose, the seeds of a stoicolosa of be-

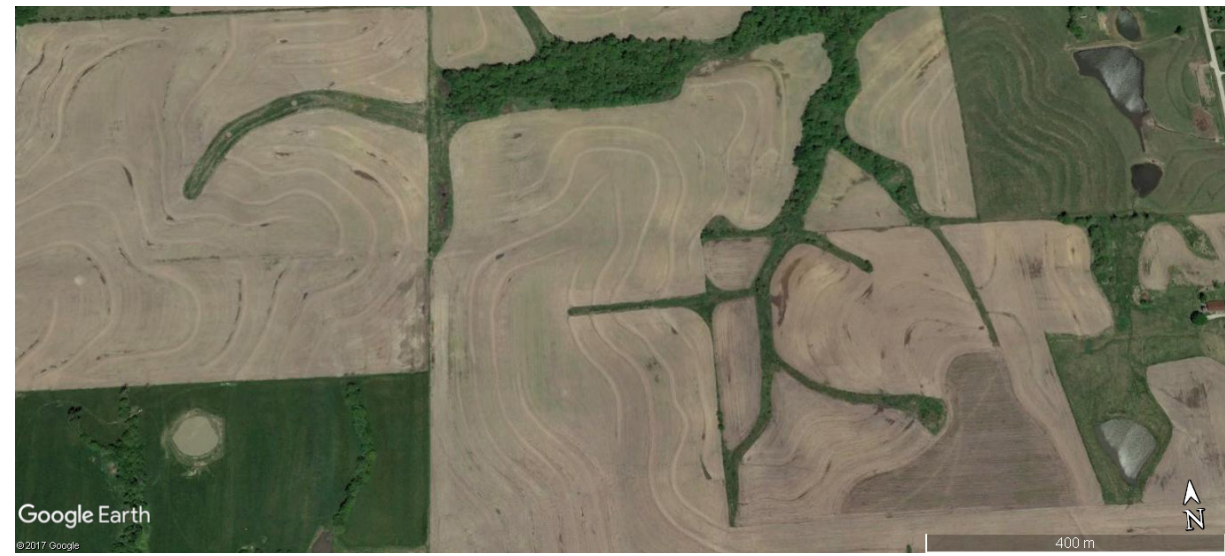

Figure 2. Example of organization of agricultural territory. Missouri State USA 
Table 1 The area of degraded lands of the territory of the territory of the NVP NUBiP Ukrainy «Velykosnitynske navchalno-doslidne hospodarstvo im. O.V. Muzychenka»

\begin{tabular}{|c|c|c|c|c|c|}
\hline Name & Area, ha & $\begin{array}{c}\text { Seeding rate } \\
\mathrm{kg} / \mathrm{ha}\end{array}$ & $\begin{array}{c}\text { Number } \\
\text { of seed } \\
\text { material, kg }\end{array}$ & $\begin{array}{l}\text { Cost of a } \\
\text { kilogram of } \\
\text { seed, UAH }\end{array}$ & $\begin{array}{c}\text { Seed costs, } \\
\text { UAH }\end{array}$ \\
\hline Object 1 & 6,14 & \multirow[t]{7}{*}{18} & 110,52 & \multirow[t]{7}{*}{80} & 8841,6 \\
\hline Object 2 & 1,24 & & 22,32 & & 1785,6 \\
\hline Object 3 & 1,35 & & 24,3 & & 1944 \\
\hline Object 4 & 0,59 & & 10,62 & & 849,6 \\
\hline Object 5 & 4,79 & & 86,22 & & 6897,6 \\
\hline Object 6 & 1,04 & & 18,72 & & 1497,6 \\
\hline Object 7 & 0,87 & & 15,66 & & 1252,8 \\
\hline Amount & 16,02 & & 288,36 & & 23068,8 \\
\hline
\end{tabular}

telless were selected, which yields a high yield of green mass (up to 100 ts / ha of hay) and has a well-developed root system that provides minimal soil flushing. The price of a kilogram of seeds is $80 \mathrm{UAH}$, the norm for sowing the stomach is $18-20$ $\mathrm{kg} / \mathrm{ha}$ [14]. After calculating the costs for the seed material, it was calculated that for complete sowing of erosion-hazardous areas it is necessary $288.36 \mathrm{~kg}$. seeds, which in monetary terms equals 23068,8 UAH.

We will calculate the funds that the management of the economy annually spends on the cultivation and introduction of pesticides on these sites. Data on fuel costs are shown in Table 2

\section{Table 2 Calculation of costs for the cultivation of degraded areas}

\begin{tabular}{|c|c|c|c|c|}
\hline $\begin{array}{l}\text { The name of the } \\
\text { operation }\end{array}$ & $\begin{array}{c}\text { Fuel } \\
\text { consumption } \\
\text { per } 1 \text { hectare }\end{array}$ & $\begin{array}{l}\text { Cost } 1 \mathrm{~L} \\
\text { fuel }\end{array}$ & $\begin{array}{c}\text { Area, } \\
\text { ha }\end{array}$ & $\begin{array}{c}\text { Total cost of fuel materials } \\
\text { for the cultivation of } \\
\text { degraded lands, UAH }\end{array}$ \\
\hline Plowing & 18,5 & \multirow{9}{*}{22,5} & \multirow{9}{*}{16,02} & \multirow{9}{*}{18346,91} \\
\hline Harrowing (to the stairs) & 1,9 & & & \\
\hline Harrowing (after stairs) & 1,5 & & & \\
\hline Cultivation & 2,5 & & & \\
\hline Bisking & 4,4 & & & \\
\hline $\begin{array}{l}\text { Sowing (grains, } \\
\text { sunflower, corn) }\end{array}$ & 2,9 & & & \\
\hline $\begin{array}{l}\text { Multi-row cultivation } \\
\text { (sunflower, corn) }\end{array}$ & 3,5 & & & \\
\hline $\begin{array}{l}\text { Spraying (irrigation, } \\
\text { cultivation with } \\
\text { herbicides) }\end{array}$ & 0,7 & & & \\
\hline Direct harvesting & 15 & & & \\
\hline Amount & 50,9 & & & \\
\hline
\end{tabular}


Fuel consumption data is taken as an arithmetic mean for the following tractor brands: K-700, K-744, T-150K, John-Dir 8100 (240 hp), MTZ-1221, MTZ-82. For harvesting: Don-1500B, SK-5 «Niva», CLAAS MEGA 208. [9] I would like to note that the calculation does not include the cost of depreciation of equipment.

The calculation of the cost of pesticides for the cultivation of the studied areas will be based on the value of the herbicide of the arena «Arena» cost of which is $577.50 \mathrm{UAH} /$ liter., And the rate of introduction of 1-2 1 per hectare. After calculating it is determined that the introduction of pesticides on these sites requires 13877.32 hryvnia.

A set of agricultural crops was made on the basis of crop rotation of the farm for 2016, while calculating the costs, the minimum rules for the input of seed material were taken into account.[10] The cost of seed material is based on prices in 2017.[14]
We can conclude that we are seeing savings in planting of erosion-hazardous areas. The cost of involvement is UAH 23068,8, while the savings for the withdrawal of the territories in one year is $51,409.77$ hryvnia.

The first step towards establishing a concept for the development of agricultural land use will be the implementation of a number of measures to remove from the cultivation of unproductive and degraded land, or land subject to degradation. Planting of such territories with long-term vegetation will bring not only positive ecological effect, but also will allow to avoid costs for cultivating agricultural crops on unproductive lands.

Innovation is the development, based on the continuous search and use of new ways and areas of realization of potential [8]

Managers of large farms often do not know the exact size of their own crops

\section{Table 3 Calculation of costs for seed material}

\begin{tabular}{|c|c|c|c|c|c|}
\hline Culture & $\begin{array}{c}\text { Sowing } \\
\text { rate } \mathrm{kg} \\
/ \mathrm{ha}\end{array}$ & $\begin{array}{c}\text { Cost of seed } \\
\text { material, } \\
\text { UAH / kg }\end{array}$ & $\begin{array}{l}\text { The cost } \\
\text { of seeds } \\
\text { per } 1 \text { ha. }\end{array}$ & $\begin{array}{c}\text { The cost of seeds, } \\
\text { which are planted } \\
\text { degraded areas }\end{array}$ & $\begin{array}{l}\text { Seed costs } \\
\text { (average } \\
\text { for all crops) }\end{array}$ \\
\hline Winter wheat & $160-250$ & 5 & 800 & 12816 & \multirow{15}{*}{19185,55} \\
\hline Wheat Yara & $160-270$ & 8 & 1280 & 20505,6 & \\
\hline Winter rye & $150-250$ & 19,2 & 2880 & 46137,6 & \\
\hline Winter barley & $160-220$ & 6 & 960 & 15379,2 & \\
\hline Soya & $40-60$ & 20 & 1200 & 19224 & \\
\hline Oat & $150-220$ & 10 & 1500 & 24030 & \\
\hline Buckwheat & $80-100$ & 25 & 2000 & 32040 & \\
\hline Pea & $220-330$ & 6,8 & 1496 & 23965,92 & \\
\hline Winter Rape & $4-6$ & 22 & 88 & 1409,76 & \\
\hline Seeds of flax & $40-70$ & 25 & 1000 & 16020 & \\
\hline Beetroot is forage & $10-15$ & 120 & 1200 & 19224 & \\
\hline Clover & $15-20$ & 80 & 1200 & 19224 & \\
\hline Alfalfa & $10-15$ & 110 & 1100 & 17622 & \\
\hline Corn for corn & $15-25$ & 40 & 600 & 9612 & \\
\hline Corn & $30-40$ & 22 & 660 & 10573,2 & \\
\hline
\end{tabular}


area, due to their constant change, due to various kinds of natural and administrative processes. The restoration of cartographic material, which was previously carried out on state money, practically ceased. The work is carried out on the basis of maps 10-15 years old, which does not reflect the realities of today [2].

Therefore, the second step to achieve the development of agricultural land use should be the creation of databases in the form of a geoinformation portal reflecting the main indicators of the economy: the state of soils, the content of trace elements in the soil complex, the state of irrigated land, the structure of sown areas and the yield of specific crops in specific fields.

The interface of the US Geonformation Portal is shown in the figure 3, the data is updated every 5 years and is freely available. A comparative analysis of changes at the national and regional levels is conducted.

Creation of a geoinformation portal should be based on a reliable information base, which we can obtain through the monitoring of land management. The obtained materials will make it possible to conduct an analysis of the existing state of land resources at all levels, from the state of soil cover and erosion processes to the content of trace elements on specific land plots, which will enable agronomists to draw conclusions about the need for additional application of mineral fertilizers in selected fields of fields. This approach will provide significant savings in the application of mineral and organic fertilizers, since rationing and dosage of the latter will be formed on the basis of reliable information. The geoportal should contain information about:

- The structure of land use

- Crop yield level in the context of alternating crops in crop rotations

- Qualitative soil condition

- Water-air soil condition

- Changes that occur during land use

V.A. Bogdanets believes that the concept of geoportal as a means of obtaining geodata on land resources, their properties, their current state of use,

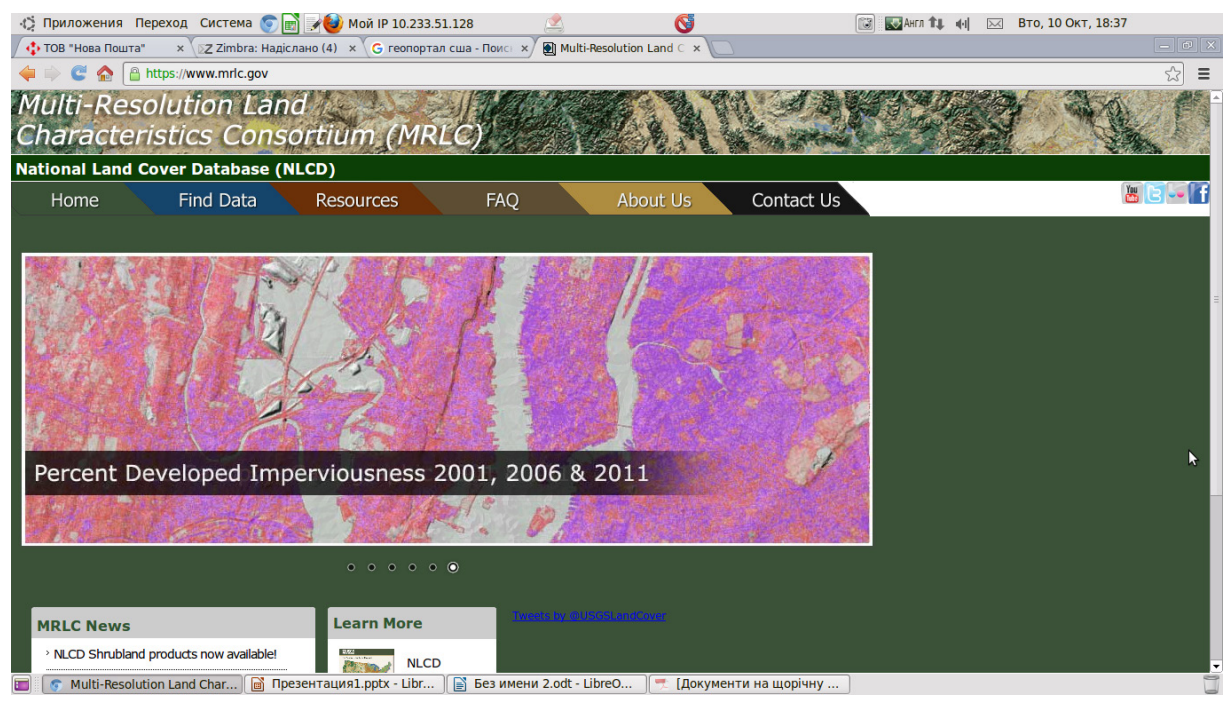

Figure 3 An example of the interface of the Geoinformation Portal of the USGS Geological Survey 
and in the historical perspective enables them to realize the main requests of potential users in the field of land management and management of territories. [4]

The third step in creating a development concept is the constant, systematic update and accumulation of data. Information should be updated annually, for systematic analysis and the provision of sound ideas for obtaining high yields of agricultural products while respecting the principles of rational land use.

\section{Conclusions:}

The article substantiates that the development of agricultural land use can not be realized without an integrated, well-founded scientific approach and monitoring of land. It is proposed to create a vivid and reliable information resource in the form of a special geoportal, which will become a new innovative element of disclosure of information. The materials collected in the information portal described above will provide all the necessary data to profile specialists, which will allow us to draw conclusions about the need for appropriate measures to be taken at individual sections of the field with the possibility of visualization. This approach will ensure cost savings when fertilizing, seed material and promotes the adoption of managerial decisions in shaping the land development strategy and land use based on reliable information.

\section{References}

1. United States Department of Agriculture Foreign Agricultural Service : [Elektronnyi resurs]. - Avaliable at : http://www.pecad. fas.usda.gov/

2. Beiker D. Chto nuzhno kulturam, poseiannym po tekhnolohyy «NO-TILL», chtob stat vysokorentabelnumy / D. Beiker // Self-recovering tillage on the basis of a systematic approach: collection of reports VII-th Intern. Conf. on soil-protecting agriculture, June 23-27, 2009: abstracts of the doc. Dnepropetrovsk, 2009. - S. 45-48.

3. Belolipskyi V. A. Kompleksne modeliuvannia otsinky ekolohichnoho stanu ahrolandshaftiv [Complex modeling the environmental condition of agricultural]./ V. A. Belolipskyi, V. O. Hrekov, A. A. Pokotylo // Visnyk ahrarnoi nauky. - 2008. - № 6 - S.51-56.

4. Bohdanets V. la. Osoblyvosti rozroblennia heoportalu kartohrafichnoi informatsii pro zemelni resursy [Features of geoportal development of cartographic information about land resources]s. 98

5. Butenko le.V., Kharytonenko R.A. Efektyvnist vedennia monitorynhu zemel z vykorystanniam danykh dystantsiinoho zonduvannia [Efficiency of monitoring of land using remote sensing data] s. 39

6. Butenko le.V Kharytonenko R.A Proiavy dehradatsiinykh protsesiv na zemliakh krainy: prychyny i naslidky [Manifestations of land degradation processes in the country: the causes and consequences] №12'2014. S.91.

7. Dorosh I.M. Zemelna reforma na rehionalnomu rivni (na prykladi Kyivskoi oblasti za 1991-2011 rr.)[Land reform at the regional level (for example, the Kiev region for 1991 2011) / I.M. Dorosh, S.O. Osypchuk, M.P. Stetsiuk, O.S. Dorosh - K. : VIPOL, 2011. $182 \mathrm{~s}$.

8. Kontseptualni osnovy upravlinnia innovatsiinym protsesom na zasadakh marketynhu. [Elektronnyi resurs]. - Avaliable at: http://buklib.net/books/37674/

9. Normy vyrabotky [Elektronnyi resurs]. Avaliable at: https://studfiles.net/preview/3823699/

10. Normy vysivu ahrokultur [Elektronnyi resurs]. - Avaliable at: https://yablukom. com.ua/uk/tsikavo-znatu/658-normi-visivu-kultur 
11. Petrychenko V. Monitorynh zemel yak riativnyi kruh [Land monitoring as a rescue circle]/ V. Petrychenko, S. Baliuk, V. Medvediev // Uriadovyi kur'ier. - 2014. - 12 kvitnia. - № 68. - S. 8.

12. Sokhnych A. la., Irtyshcheva I. O Innovatsii v period ekonomichnykh transformatsii [Innovations in the period of economic transformations]

13. Tretiak A., Kuryltsyv R., Tretiak N. «Kontseptualni zasady rozvytku v Ukraini suchasnoi bahatofunktsionalnoi systemy upravlinnia zemelnymy resursamy" [Conceptual framework for the development of modern multifunctional land management system in Ukraine] Zemlevporiadnyi visnyk №9 2013r., s-28.

14. Urozhai [Elektronnyi resurs]. - Access mode: http://urozhai.com/?q=uk

Є.В. Бутенко, В.В.Степанець

ІННОВАЦІЙНІ ЗАСАДИ ОРГАНІЗАЦІї, ВИКОРИСТАННЯ ТА ОХОРОНИ СІЛЬСЬКОГОСПОДАРСЬКИХ ЗЕМЕЛЬ

В статmі досліджено інноваційні засади розвитку. Висвітлено роль моніторингу земель в веденні сільсько- господарського землекористування та передумови вдосконалення сільського господарства. Запропоновано концепцію сталого розвитку використання земельних ресурсів. Описано зарубіжний досвід та напрямки зростання сталого землекористування.

Ключові слова: моніторинг земель, інноваційні засади, землекористування, охорона земель.

\section{$* * *$ \\ Бутенко Е. В. , Степанець В.В. ИННОВАЦИОННЫЕ ОСНОВЫ ОРГА- НИЗАЦИИ, ИСПОЛЬЗОВАНИЯ И ОХРАНЫ СЕЛЬСКОХОЗЯЙСТВЕННЫХ ЗЕМЕЛЬ}

В статье исследованы инновационные основы развития. Освещена роль мониторинга земель в ведении сельскохозяйственного землепользования и предпосылки совершенствования сельского хозяйства. Предложена концепция устойчивого развития использования земельных ресурсов. Описаны зарубежный опыт и направления роста устойчивого землепользования.

Ключевые слова: мониторинг земель, инновационные принципы, землепользования, охрана земель. 